\title{
Multifocal inflammatory myofibroblastic tumor in the abdomen
}

\author{
C. Müller ${ }^{1}$, T. Bernig ${ }^{2}$, W. Barthlen ${ }^{3}$ \\ 1. Division of Pediatric Surgery, University Greifswald, Greifswald, Germany. 2. Department of Pediatric Oncology, \\ University Halle, Halle, Germany. 3. Department of Pediatric Oncology, University Greifswald, Greifswald, Germany.
}

Correspondence: C. Müller. M.D. Address: Ltd. OA Dr. med. Division of Pediatric Surgery, University medicine Greifswald, F-Sauerbruchstr. 1D-17475 Greifswald, Germany. E-mail: carsten.mueller@uni-greifswald.de

Received: May 27, 2013

DOI : $10.5430 / j b g c . v 4 n 1 p 42$

Accepted: September 18, 2013

URL: http://dx.doi.org/10.5430/jbgc.v4n1p42

Online Published: November 15, 2013

\section{Abstract}

A 17 year old so far healthy young man presented with upper abdominal pain. Imaging with sonography, MRT and PET-CT demonstrated three solid mass in the duodenal mesentery, pancreatic corpus and tail and on the upper pole of the left kidney. Open biopsy of the mesenterial mass revealed an inflammatory myofibroblastic tumor which was ALK-1 negative. Chemotherapy with vincristine, actinomycin D and cyclophosphamide was initiated and the imaging control after four cycles exhibited morphological and functional regression at all three mass locations. Surgery in curative intention was now performed and the nodules in the mesentery and the kidney were totally resected. The pancreas looked macroscopically normal and only biopsies were taken. Histology showed regressive fibrosis at all sites and no malignancy. The young man has now been well for now 50 months and follow-up imaging showed no sign of recurrence so far.

\section{Key words}

Multifocal inflammatory myofibroblastic tumor, Pancreas, Kidney, Mesentery, PET-CT, MRT, Chemotherapy, Surgery

\section{Introduction}

Inflammatory myofibroblastic tumors (IMT) can arise in virtually every location ${ }^{[1-4]}$. Multifocal appearance is rare and tumors involving the pancreas are even more rare ${ }^{[5,6]}$. Most cases are localised in the lungs. Morphology is very heterogenous showing collagenous fibres, myofibroblasts, macrophages and lymphoplasmacellular infiltrates. The differentiation to sarcomas is difficult ${ }^{[7]}$. The etiology is unknown. Neoplastic, inflammatory reparative, posttraumatic and autoimmune induced processes have been discussed ${ }^{[5,8]}$. IMT's have intermediate potential to progression. Recurrences are frequent but metastasis is rare ${ }^{[9]}$. Surgical resection with clear margins is indicated whenever possible. Medically non-steroidal antiphlogistics have been administered and chemotherapy with anecdotal success. There is no clear therapeutic regimen so far. We report a case of an as yet successful therapy combining, biopsy, chemotherapy and surgery.

\section{Case report}

A 17 year old man presented with chronic left-sided upper abdominal pain. Nutritional measures showed no success and gastroscopy was normal. There was an elevation of the serum amylase (3.56 $\mu \mathrm{katal} / \mathrm{l}$; normal: $0.42 \mu \mathrm{katal} / \mathrm{l}-1.92 \mu \mathrm{katal} / \mathrm{l})$, 
lipase (33.1 $\mu \mathrm{katal} / \mathrm{l}$; normal < $4.76 \mu \mathrm{katal} / \mathrm{l})$, and $\mathrm{CrP}(19 \mathrm{mg} / \mathrm{l}$; normal < 5mg/l). Serum elastase and stool fat values were slightly elevated, otherwise no sign of endo- or exocrine pancreas insufficiency was noted. The serum tumor markers AFP, HCG, LDH, NSE were all normal as well as vanilline acid in the urine. Bone marrow aspiration was normal.

The boy was admitted to our department with a suspicion of pancreatitis. CT-Scan showed three solid nodules in the abdomen: one in the pancreatic head and corpus measuring $3.8 \mathrm{~cm} \times 8.8 \mathrm{~cm}$, one measuring $5 \mathrm{~cm} \times 5 \mathrm{~cm}$ in the duodenal mesentery ventro-caudal to the pancreas, and a hypodense solid structure $1 \mathrm{~cm} \times 3 \mathrm{~cm}$ on the upper convexity of the left kidney (see Figure 1, Figure 2).

Figure 1. Primary CT-Scan with multifocal IMT in the mesentery of the duodenum, the pancreas and the left kidney (Courtesy of H.-U. Berndt M.D., Radiology Wolgast)

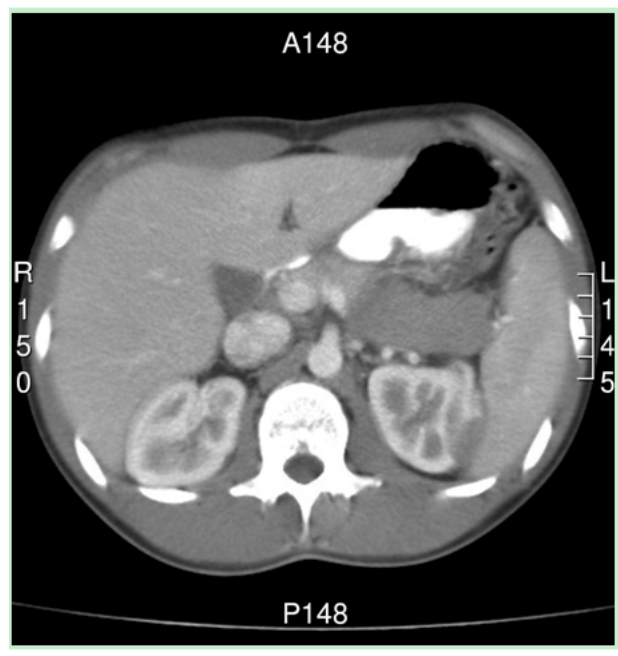

Figure 2. Sonographic Scan of the duodenal mass (Courtesy of R. Stenger, M. D. Ph. D., Department of Pediatric Intensive Care Greifswald)

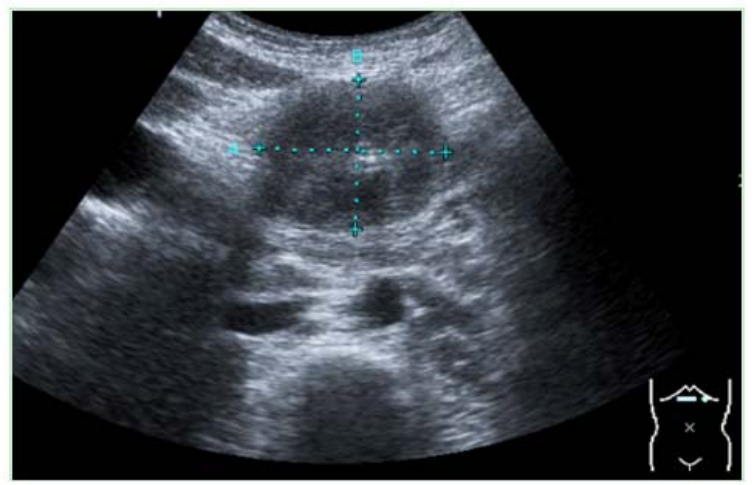

A surgical biopsy was taken from the mesenterial mass by laparotomy which revealed an inflammatory myofibroblastic tumor. ALK-1, was negative on immunohistochemistry. Reference pathology confirmed the diagnosis and after consultation of the German soft tissue sarcoma study group chemotherapy was initiated with a combination of Vincristin ${ }^{\circledR}$, Actinomycin $\mathrm{D}^{\circledR}$ and Cyclophosfamid ${ }^{\circledR}$.

Side effects were nausea and vomiting (CTCAE II) which was successfully treated with Odansetron ${ }^{\circledR}$, Dexamethason ${ }^{\circledR}$ und Aprepitant ${ }^{\circledR}$, and a peripheral sensory neuropathy on the finger tips.

After two cycles of chemotherapy the MRT exhibited a regression of the pancreatic mass down to $2.8 \mathrm{~cm} \times 7.3 \mathrm{~cm}$ width with partly necrosis (see Figure 3).

Two further cycles of chemotherapy were administered. Thereafter the PET-CT (280 MBq 18F-Fluordexoglycose) showed a further regression of the foci in the duodenal mesentery and the pancreas, but still with a considerable metabolic activity (see Figure 4, Figure 5). 
Figure 3. MRT-Scan after two cycles of chemotherapy. A regression of the tumors in the duodenal mesentery and pancreas can be seen. (Courtesy of C. Weigel, M.D., Clinic of Radiology University Greifswald)

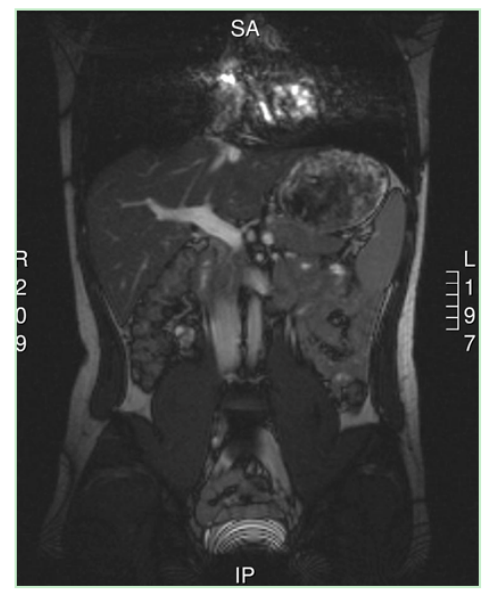

Figure 4. PET-CT-Scan with high activity of the tumor in the duodenal mesentery. (Courtesy of H. Amthauer M.D. PhD., Charité Berlin, Dept. of Nuclear Medicine)

Figure 5. PET-CT-Scan with high mass activity in pancreas and duodenal mesentery. (H. Amthauer M. D. PhD., University Magdeburg, Dept. of Nuclear Medicine)
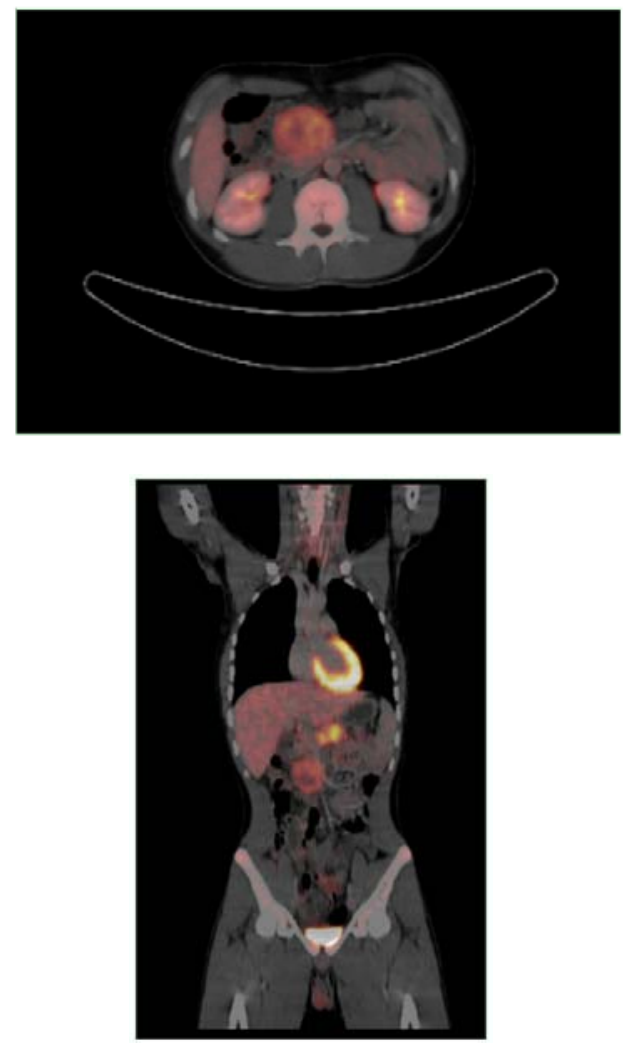

Surgery with curative intention was now performed and the tumor in the mesentery which was adjacent to the duodenum could be totally removed. The renal focus was resected by organ-sparing partial nephrectomy.

After opening of the lesser sack the pancreas looked macroscopically normal. Therefore, only small biopsies were taken from the head and corpus. The postoperative course was totally uneventful. Histopathological examination of the mesenterial and renal focus revealed regressive sequelae of the IMT without signs of malignancy and in the pancreas only massive fibrosis. Six months after surgery the patient is well and free of disease as assessed by repeat MRT so far.

\section{Discussion}

The rare inflammatory myofibroblastic tumors can mimick malignant processes. Locations most frequently described are the lungs and orbita ${ }^{[3,8,10]}$. The first description of an IMT in the lung was by Philips in 1937. Multifocal occurrence 
including stomach and pancreas have been described. In childhood IMT's have been reported to arise in the liver, intestinal mesentery, retroperitoneal space and bladder ${ }^{[7,8,11-14]}$.

Age distribution is from 10 months to 80 years with a median of 37 years. Males are affected more frequently with a factor of 2.9. Clinical symptoms are fever, anemia and loss of weight.

Aetiopathogenesis is not clear yet. Numerous infections with grampositive cocci, Klebsiellae pneumoniae or E. coli have been discussed as well as viral or parasitic infections, immunologic or allergic reactions ${ }^{[15]}$. An accumulation of cases has been observed in the Asian area which raises the possibility of a genetic susceptibility.

Histopathologically, IMT's are characterised as a pseudosarcomatous inflammatory process in the soft tissue. The tumor consists of spindle cells with an infiltration of plasma cells, lymphocytes and eosinophils with fibrous connecting tissue in various distribution. Synonymous are plasma cell granuloma, histiocytoma, pseudolymphoma and fibroxanthoma. Diagnosis is not possible clinically or by imaging alone and can only be achieved by surgical biopsy. Differentiation with soft tissue sarcoma is difficult ${ }^{[15]}$ : If myofibroblasts can be demonstrated by light microscopy and immunohistochemistry a myofibroblastic sarcoma must be diagnosed, even without a fibronexus ${ }^{[16]}$. Lymphoma can be diagnosed by immunohistochemical analysis of T- and B-cell subpopulations ${ }^{[5,10,17]}$.

Imaging is performed in the first line by CT and MRT. In the MRT with fat-saturated T1-sequence the tumor can be visualized as a homogenous signal-poor process, and in the T2-sequence as an inhomogenous signal-rich tumor with ill-defined boundaries. In our case, the regression of the tumor after chemotherapy could be seen in the PET-CT (see Figure 4, Figure 5). Follow-up can also be performed using Doppler-sonography which shows the inhomogenity and hypoperfusion of the tumors ${ }^{[18]}$.

It has been reported that approximately half of the IMT's have gene mutations which activate the anaplastic lymphom kinase ALK (ALK-receptor tyrosinkinase gene on the short arm of chromosome $2 / 2 \mathrm{p} 23^{[2,5,9,19]}$. Similar to the anaplastic giant cell lymphomas ALK-positive and - negative IMT's have different clinical and prognostic behaviour. ALK- positive IMT's seem to have a tendency to occur in younger age groups and to early recurrence, whereas ALK-negative IMT's occurred in higher age gropus and had a tendency to metastasis. In a recent report, a positive expression of ALK, which is a tyrosin kinase oncogene, is an argument to render the lesion to the low grade sarcomas ${ }^{[17]}$.

After establishing the diagnosis a conservative approach with non-steroidal antiphlogistics has been advocated ${ }^{[13]}$. Complete surgical resection of all tumors, however, offers the only chance for cure ${ }^{[20]}$. Radical surgery should be attempted, whenever possible, without mutilating the frequently young patients. In our case the 4 cycle chemotherapy with Vincristin ${ }^{\circledR}$, Actinomycin $\mathrm{D}^{\circledR}$ and Cyclophosfamid ${ }^{\circledR}$ before surgery was so efficient, that a organ-sparing resection of all known tumors could be achieved without the need to touch the pancreas. It remains to be elucidated, however, if our patient eventually remains free of disease over the years and if endo- or exocrine pancreatic insufficiency finally develops.

\section{References}

[1] Dall'Igna P, Cecchetto G, Guglielmi M, Alaggio R. Clinical and pathologic considerations in a case of inflammatory myofibroblastic tumor of the spleen. Pediatr Surg Int. 2004 Dec; 20 (11-12): 875-7. PMid: 15164216. http://dx.doi.org/10.1007/s00383-004-1155-1

[2] Gleason BC, Hornick JL. Inflammatory myofibroblastic tumours: where are we now? J Clin Pathol. 2008 Apr; 61 (4): 428 -37. PMid: 17938159. http://dx.doi.org/10.1136/jcp.2007.049387

[3] Goldin SB, Osborne D, Paidas C, Iannello J, Gilbert-Barness E, Karl R, et al. Inflammatory myofibroblastic tumor of the midesophagus. Fetal Pediatr.

[4] Sahnoun L, Elezzi O, Maazoun K, Krichene I, Jouini R, Mekki M, et al. Ovarian inflammatory myofibroblastic tumor in children. J Pediatr Adolesc Gynecol. 2007 Dec; 20 (6): 365-6. PMid: 18082859. http://dx.doi.org/10.1016/j.jpag.2007.05.006 
[5] Mizukami H, Yajima N, Wada R, Matsumoto K, Kojima M, Kloppel G, et al. Pancreatic malignant fibrous histiocytoma, inflammatory myofibroblastic tumor, and inflammatory pseudotumor related to autoimmune pancreatitis: characterization and differential diagnosis. Virchows Arch. 2006 May; 448 (5): 552-60. PMid: 16538442. http://dx.doi.org/10.1007/s00428-006-0157-x

[6] Sim A, Lee MW, Nguyen GK. Inflammatory myofibroblastic tumour of the pancreas: Can J Surg. 2008 Feb; 51 (1):E23-4. Pathol. 2007 Sep-Dec; 26 (5-6): 243-54.

[7] Zanger P, Kronsbein U, Merkle P, Bosse A. Inflammatory myofibroblastic tumor of the pancreas with regional lymph node involvement. Pathologe. 2002 Mar; 23 (2): 161-6. PMid: 12001534. http://dx.doi.org/10.1007/s00292-002-0523-7

[8] Stuckmann G, Flury R, Heinz W, Strunk H. Inflammatory myofibroblastic tumour (so-called pseudotumour) of the hepatobiliary system. Ultraschall Med. 2004 Sep; 25 (5): 373-6. PMid: 15368142. http://dx.doi.org/10.1055/s-2004-813169

[9] Coffin CM, Hornick JL, Fletcher CD. Inflammatory myofibroblastic tumor: comparison of clinicopathologic, histologic, and immunohistochemical features including ALK expression in atypical and aggressive cases. Am J Surg Pathol. 2007 Apr; 31 (4): 509-20. PMid: 17414097. http://dx.doi.org/10.1097/01.pas.0000213393.57322.c7

[10] Schlimper C, Sommer T, Flacke S, Wolff M, Schild H, Kreft B. Radiologic features of inflammatory pseudotumors. Rofo. 2005 Nov; 177 (11): 1506-12. PMid: 16302131. http://dx.doi.org/10.1055/s-2005-858633

[11] Al-Taie OH, Mork H, Jenett M, Klein D, Muller JG, Scheurlen M. Fast-growing gastric inflammatory pseudotumor: a rare manifestation of peptic ulcer disease. Endoscopy. 2002 Mar; 34 (3): 239. PMid: 11870578.

[12] Czauderna P, Schaarschmidt K, Komasara L, Harms D, Lempe M, Vorpahl K, et al. Abdominal inflammatory masses mimicking neoplasia in children-experience of two centers. Pediatr Surg Int. 2005 May; 21 (5): 346-50. PMid: 15815933. http://dx.doi.org/10.1007/s00383-005-1410-0

[13] Karnak I, Senocak ME, Ciftci AO, Caglar M, Bingol-Kologlu M, Tanyel FC, et al. Inflammatory myofibroblastic tumor in children: diagnosis and treatment. J Pediatr Surg. 2001 Jun; 36 (6): 908-12. PMid: 11381424. http://dx.doi.org/10.1053/jpsu.2001.23970

[14] Yan J, Peng C, Yang W, Wu C, Ding J, Shi T, et al. Inflammatory pseudotumour of the spleen: report of 2 cases and literature review. Can J Surg. 2008 Feb; 51 (1): 75-6. PMid: 182487.

[15] Schuessler G, Fellbaum C, Fauth F, Jacobi V, Schmidt-Matthiesen A, Ignee A, et al. The infammatory pseudotumour -- an unusual liver tumour. Ultraschall Med. 2006 Jun; 27 (3): 273-9. PMid: 16767617. http://dx.doi.org/10.1055/s-2005-858530

[16] Kuhnen C, Homann HH, Mentzel T. Myofibroblastic sarcoma of the thoracic wall. Change in appearance in tumour recurrence. Pathologe. 2003 Mar; 24 (2): 128-35. PMid: 12673503.

[17] Qiu X, Montgomery E, Sun B. Inflammatory myofibroblastic tumor and low-grade myofibroblastic sarcoma: a comparative study of clinicopathologic features and further observations on the immunohistochemical profile of myofibroblasts. Hum Pathol. 2008 Jun; 39 (6): 846-56. PMid: 18400254. http://dx.doi.org/10.1016/j.humpath.2007.10.010

[18] Stenger R, Kaufhold A, Bachmaier A, Weigel C, Müller C, Huber S, et al. Multifokale inflammatorisch-myofibroblastische Tumoren (IMTF) im Abdomen - Relevanz der Sonografie und weiteren Bildgebungen (Kasuistik) Ultraschall in Med. 2008 ; 29. http://dx.doi.org/10.1055/s-0028-1085889

[19] Mosse YP, Laudenslager M, Longo L, Cole KA, Wood A, Attiyeh EF, et al. Identification of ALK as a major familial neuroblastoma Predisposition gene. Nature. 2008 Oct 16; 455 (7215): 930-5. PMid: 18724359. http://dx.doi.org/10.1038/nature07261

[20] Janik JS, Janik JP, Lovell MA, Hendrickson RJ, Bensard DD, Greffe BS. Recurrent inflammatory pseudotumors in children. J Pediatr Surg. 2003 Oct; 38 (10): 1491-5. http://dx.doi.org/10.1016/S0022-3468(03)00501-3 